\title{
The Effect of Tillage Methods on the Productivity of Tilled Crops and Soil Fertility
}

\author{
Nurbiy Iljasovich Mamsirov, Yuri Alekseevich Chumachenko, Asker Cherimovich Udzhuhu, \\ Kazbek Khalidovich Khatkov
}

\begin{abstract}
The article presents the results of a long-term research in establishing the share of the effect of various methods and systems of primary soil cultivation on the productivity of maize and sunflower, as well as soil fertility on the territory of the Raduga farm in the Giaginsk district of the Republic of Adygea. The studies were performed according to the following tillage systems: soil plowing to the depth of $25-27 \mathrm{~cm}$ (continuously (reference)); chisel soil plowing to the depth of $38-40 \mathrm{~cm}$ (continuously); surface soil tillage to the depth of $10-12 \mathrm{~cm}$ (continuously); and combined tillage system. The study has established the fact of troubled forming of the optimal maize and sunflower plant density due to the decreased germination with the loose structure of the seed layer. Improper choice of the primary tillage method, deficiency of the required density of seedlings in some years reached $20 \%$ or more. However, after combined tillage, it reduced 1.5 - 2.0 times. During the study, by the methods of primary tillage, the lowest weed infestation of maize and sunflower was noted on the background of plowing to the depth of $25-27 \mathrm{~cm}$, and was before harvesting lower by $30-80 \%$ than in other tillage variants. The same regularity was observed in counting the number of pests on tilled crops. In the case of continuous surface tillage, an increase in the number of harmful larvae was noted in the variant of plowing to the depth of $25-27$ cm - within $31-96 \%$.

The highest average sunflower yield was achieved in the variant with combined (based on selection) system of soil tillage, where the growth was determined by increased fertilizer rates and ranged from $20 \%$ (in the case of plowing) to $31 \%$ (in the case of combined tillage). The decrease in the yield of grain maize after replacing plowing of compact chernozem with heavy disc harrowing did not exceed $8 \%$, and in the case of long-delayed sowin, it was at the level of $19-28 \%$.
\end{abstract}

Keywords: soil, leached chernozem, sowing density, weed infestation, phytosanitary state, diseases, pests, tilled crops, maize, sunflower, tillage, yield.

Revised Manuscript Received on October 30, 2019.

* Correspondence Author

Nurbiy Iljasovich Mamsirov, Maykop State Technological University, Maykop, Russia.

Yuri Alekseevich Chumachenko, Maykop State Technological University, Maykop, Russia.

Asker Cherimovich Udzhuhu, All-Russian Rice Research Institute, Krasnodar, Russia

Kazbek Khalidovich Khatkov, State Scientific Institution Adygeyskiy Research Institute of Agriculture, Maykop, Russia.

(C) The Authors. Published by Blue Eyes Intelligence Engineering and Sciences Publication (BEIESP). This is an open access article under the CC BY-NC-ND license (http://creativecommons.org/licenses/by-nc-nd/4.0/)

\section{INTRODUCTION}

In modern conditions, resource saving in terms of rational and efficient use of natural resources and increasing the return on investment, rather than reducing costs, is especially significant. A real way of solving this problem lies in adapting and improving the agricultural technologies.

The main purpose of the study was determining effective agronomic measures for increasing the yield of sunflower and maize based on the rational use of soil fertility in accordance with the biological requirements of these crops.

In modern agriculture, due to the intersection of environmental, economic, and demographic problems, aggravation of the energy crisis, and due to the advances of science and technology, farming systems of the new generation — adaptive-landscape systems - are being developed and introduced.

The main purpose of developing and introducing adaptive-landscape farming systems is sustainable reproduction of the resources and the environment of the technological cycle for obtaining the required amounts and quality of product (in the conditions of highly productive agricultural landscapes that are resistant to unfavorable natural and technogenic factors) [1]. Agricultural practices and activities are controlling actions on farming ecosystems. They change in time, and the necessity or expediency of using them is determined by the actual state in the following periods: pre-sowing; planting - the beginning of intensive growth; intensive formation of the yield (before emergence of panicles in maize, at the beginning of sunflower basket formation); pre-harvesting state. Assimilation of high technologies in the present economic state of agricultural producers of the Republic is unrealistic yet, since these technologies are introduced through the scientific and technological progress, an integral part of which is the availability of expensive machinery. With the current economic situation of agricultural enterprises in the Republic of Adygea, a realistic focus should be placed on intensive agricultural technologies aimed at obtaining high quality of the planned corn and sunflower yield. The perspectivity of these activities is ensured by the wide possibility of maneuvering in the choice of controlling actions.

The limited nature (lack due to the circumstances) of anthropogenic resources predetermines the necessity of their rational (and therefore efficient) use realized through the optimization of controlling actions. 


\section{The Effect of Tillage Methods on the Productivity of Tilled Crops and Soil Fertility}

All agrotechnological measures aimed at reducing the costs while achieving high economic effect should be formed in view of achieving the optimal pre-harvest condition of tilled agricultural lands, i.e., density of plants and the minimum presence of weeds.

The success or failure of reaching the given density of seedlings (the "bottleneck" of the industrial resource-saving tilled crop technologies) depends not only on the humidity, but also on the agro-physical state of the seed layer. Along with this, primary tillage has a decisive effect on crops contamination, soil state, and the quality of its pre- and post-harvesting treatment.

Scientific literature contains a significant number of analyses of the results of experimental materials about soil tillage for maize. As noted by A. M. Almazov [2], among primary tillage methods, the main one is plowing. The main mass of maize roots is within the $0-30 \mathrm{~cm}$ layer, thus, it reacts strongly to the depth of plowing. It should be determined with regard to the soil difference and zonal features.

The existing generalizations of the methods of primary soil tillage and their practical use have the zonal nature rather than the adaptive-landscape one, which is determined by the hydration of large agricultural regions [3]-[8]. However, moisture has not only the climatic, but also the weather factor.

\section{OBJECTS AND METHODS}

To address this goal, field experiments were laid in 2016 2018 for determining the effect of various methods and systems of primary tillage on maize and sunflower productivity and soil fertility on the territory of the Raduga farm in the Giaginsk district of the Republic of Adygea. During the experiment, the most agronomically valuable top root layer of soil was studied; therefore, $10 \mathrm{~cm}$ soil samples for analyses were taken to the depth of $40 \mathrm{~cm}$.

This experiment was laid on the fields of economic crop rotation in the link: winter wheat after annual herbs - maize for silage - sunflower - winter wheat.

The experiment was repeated three times. The variants of soil tillage were applied in three blocks with both levels of fertilization. The variants (the units, fertilization backgrounds, and methods of tillage within them) were placed randomly. The randomization set in the year of laying the experiment under all subsequent crops remained unchanged.

The total (sown) area of the experimental plots was in the range between $2,250 \mathrm{~m}^{2}(15 \mathrm{x} 150)$ and $2,500 \mathrm{~m}^{2}(10 \times 250)$. The reference plots were at least half of the sowing plots, and in some cases varied across the variants (exclusions for various reasons).

The scheme of this experiment involved the following variants of the tillage system: 1 ) plowing to the depth of $25-$ $27 \mathrm{~cm}$ (continuously (reference)); 2) chisel plowing to the depth of $38-40 \mathrm{~cm}$; 3) surface soil tillage to the depth of $10-$ $12 \mathrm{~cm}$ (continuously); and 4) combined tillage system. The last one was not related to the order of crops alternation, and was only based on the choice of the method of primary tillage to its time, based on the number and the distribution of moisture in the $40 \mathrm{~cm}$ layer of soil.

The tillage systems were superposed on two backgrounds of fertilization - the moderate and the high. Moderate rates of mineral fertilizers were the following: maize for silage $\mathrm{N}_{75} \mathrm{P}_{45} \mathrm{~K}_{45}$ (the main being $\mathrm{N}_{45} \mathrm{P}_{45} \mathrm{~K}_{45}$, the additional $-\mathrm{N}_{30}$ ), sunflower - $\mathrm{N}_{30} \mathrm{P}_{30} \mathrm{~K}_{30}$ being the primary. High rates were the following: maize $-\mathrm{N}_{165} \mathrm{P}_{105} \mathrm{~K}_{55}$ (primary $-\mathrm{N}_{90} \mathrm{P}_{60}$, at sowing - $\mathrm{N}_{15} \mathrm{P}_{15} \mathrm{~K}_{15}$, additional $-\mathrm{N}_{60} \mathrm{P}_{40}$ ), sunflower $\mathrm{N}_{75} \mathrm{P}_{75} \mathrm{~K}_{15}$ (primary $-\mathrm{N}_{60} \mathrm{P}_{60}$, at sowing $-\mathrm{N}_{15} \mathrm{P}_{15} \mathrm{~K}_{15}$ ).

\section{RESULTS AND DISCUSSION}

The maximum possible (upon public demand) acreage of all, without exception, fields for crops was determined by two main factors: 1) compliance with the conditions in agricultural landscapes to the biological requirements of the cultivated plants; 2) the limits of the optimum and permissible saturation of crop rotations by these plants. In the development of projects of adaptive landscape farming systems for various farms, the crop rotation factor is taken into account after analyzing the realities of the cultivated land. The content of this chapter is presented in the same order.

It is well known that without additional investment, scientifically substantiated crop rotations ensure productive use of the arable land and its index of usage. This is also achieved through the optimal set of crops and their rotation, which creates the conditions for efficient application of mineral fertilizers, plant protection (products for fighting weeds, diseases and pests), and the introduction of energy-saving agricultural technologies. Providing opportunities for the optimal placement of agricultural crops and the reasonably high specific weight of the most productive of them is one of the main principles in designing crop rotations. With that, one should take into account the effect of crop rotations saturation with individual crops or their groups on the balance of organic matter in the soil; the possibility of compensating for the lack of humus using available organic fertilizers; the feasibility of using byproducts and green manure crops for these purposes; and the soil conservation effect of crop rotation.

The main competitors of field cultivated plants in using resources and the conditions of yield formation are weeds. Weeds infestation of crops results in reduction of all agrotechnical measures, including the use of fertilizers aimed at increasing the yields. Soil purification from the seeds and vegetative organs of weed reproduction is the preliminary step of optimizing the nutrient conditions by fertilizing Formation of $1 \mathrm{~kg}$ of dry weight of weeds requires up to 1,000 liters of water or more; for cultivated plants, this value is $2-3$ times less. Strong weed infestation removes from the soil and fertilizers the amount of nitrogen, phosphorus and potassium that is sufficient for producing three tons of grain per hectare. In NPK removal by the weeds, the share of $\mathrm{N}$ is $46 \%$, of P2O5 - $15 \%$, and of $\mathrm{K} 2 \mathrm{O}-39 \%$ [9]. Besides, weeds are a temporary habitat and an intermediate food source for many harmful insects, which propagate fungal and bacterial diseases. They affect not only the yield, but also its quality, including its safe use.

Published By: 
In the experiment, significant variation of the mass of weeds and their structure was noted. However, the trend of increasing the mass of the weeds, and the share of perennials in the line: plowing, deep subsurface tillage, surface tillage, remained every year.

The information about the mass of weeds before harvesting differentiated by the methods of tillage and the rates of fertilizers is shown in Table-I.

Table-I: Wet weight of weeds before harvesting, depending on the methods of primary tillage and fertilization rates, g/m2 $(2016-2018)$

\begin{tabular}{|l|l|l|l|l|l|l|l|l|l|l|}
\hline $\begin{array}{l}\text { Plowing to the depth of } 25- \\
27 \mathrm{~cm}\end{array}$ & $\begin{array}{c}\text { Chisel plowing to the depth } \\
\text { of } 38-40 \mathrm{~cm}\end{array}$ & $\begin{array}{c}\text { Surface plowing to the depth } \\
\text { of } 10-12 \mathrm{~cm}\end{array}$ & \multicolumn{3}{|c|}{ Combined } \\
\hline
\end{tabular}

The results clearly confirm the earlier found regularities: a high share of perennials in the total mass of weeds; a slight increase in the mass of weeds and a very substantial growth of the mass of perennial weeds in the variants with no-till tillage methods; the effect of weather conditions in certain years on the weediness of tilled crops.

In the experiment, the most significant results may be considered the following: 1) increasing the level of compact chernozem fertilization does not significantly increase the mass of weeds component; 2) infestation (by weight) was steadily lower in the variant with adjustable combination of soil treatments.

The former was due to increasing the competitiveness of the cultural agro-ecosystem due to better survival rates (increase in density) of the plants on the background of high soil fertilization rates. The latter was partly a result of strengthening the competitiveness, and, furthermore, the result of tillage of the soil that was located in a better agrophysical condition that resulted in the death of a significant number of weeds.

In the crops of each cultivar, predominance of the weeds accommodated over the centuries of evolution was observed. In tilled agrocenoses, the most widespread were annual weeds, such as Echinochloa (chicken millet) [Echinochloa crus-galli (L.) Roem. et Schult.], rice cockspur (rice millet) (Echinochloa oryzicola Vasing.), wild mustard (Sinapis arvensis L.), redroot amaranth (Amaranthus albusis L.), foxtail grass [Setaria virticillata (L.) Beauv], green foxtail [Setaria viridis (L.) Beauv], smoke-blue foxtail [Setaria glauca (L.) Beauv]; individual plants in the crops were hog bean (Noaimi pdeg L.) and barbed nightshade (Solanum rostratum Dun.). Perennial weeds were noted in the crops of both cultivars, represented by yellow thistle (Cirsium setosum M. B.), swallowwort (Aselepias ugas L.), field bindweed (Convolvulus arvensis L.), creeping crown vetch (Coronilla varia L.), whitlow peppergrass (Lepidium draba L.), leafy spurge (Euphorbia virgata Valdst et Kit), gristly spurge (Euphorbia glareosa Pall ex M. B.), hedgehog liquorice (Glycyrrhiza echinata L.) and licorice (Glycyrrhiza glabra L.), bittercress (Barbarea vulgaris R. Br.), blue lettuce (Lactuca tatarica (l.) C.A.Mey, corn sow thistle (yellow) (Sonchus arvensis L.).

Of the total annual potential crop losses in Russia caused by harmful organisms (71.3 million tons of grain units), the share of plant diseases is $45.1 \%$, the share of pests is $23.5 \%$, and of weeds - $31.4 \%$. Therefore, systematic integrated protection of the agricultural crops from pests and diseases with regard to their economic thresholds of harmfulness is a required condition for increasing the productivity in agriculture [9].

In the experiments for studying soil tillage systems, consideration of the contamination, along with definition of the parameters, has become a rule.

At the same time, assessment of the phytopathological state of tilled crops, depending on the tillage technology, and on the use of intensification is often not performed.

High efficiency of modern insecticides and fungicides has been proven in practice, and there is no doubt about it. Their use is currently constrained by the economic reasons, but in the near future, environmental constraints will be in the foreground.

It is well known that tillage is aimed at: 1) limiting the number of dormant and adult stages of pests, as it facilitates the access for entomophages; 2) deteriorating the conditions for the initial stages of pests development; and 3) reducing the number of pests in the larval stage [10], [11].

The greatest damage to corn and sunflower is caused by the larvae of click beetles (wireworms), and adult darkling beetles (false wireworms), May beetles (Melolontha melolontha (L.)), and summer chafer (Amphimallon solstitiale (Linnaeus, 1758)) due to their long stay in the soil [12]. 
Click beetles and their larvae in arable land are mainly represented by the following species: common click beetle (Agriotes sputator L.), red click beetle (Melonotus fusciceps Gyll.), and steppe click beetle (Agriotes gurgistanus Fsld.). The species of darkling beetles are cylindric darkling beetle (Cilindronotus sp.), maize darkling beetle (Pedinus femoralis G.), opatrum sabulosum (Opatrum sabulosum L.), Gonocephalum granulatum (Gonocephalum pussilum F.), and gourd darkling beetle (Genocephalum Pusillum F.).

Wireworms prevailed, the number of which over the years varied from 0.9 to 3.6 per $\mathrm{m}^{2}$ at plowing, and from 1.9 to 6.2 per $\mathrm{m}^{2}$ at surface tillage. The second place was taken by false wireworms -0.8 to 2.6 per $\mathrm{m}^{2}$, and $2.2-4.0$ per $\mathrm{m}^{2}$ accordingly, in these variants. The number of larvae of May beetles and summer chafer of various age was insignificant, and under maize in both experiments was 0.2 per $\mathrm{m}^{2}, 0.2-$ 0.3 per $\mathrm{m}^{2}$, and $0.4-0.6$ per $\mathrm{m}^{2}$, at plowing, at chisel and surface tillage, respectively. Under sunflower, they were two and more times less numerous. At plowing and chisel tillage, in more than half of the years, May beetle larvae were not found under this crop.

The increased number of all harmful larvae during chisel tillage, compared to plowing, was manifested as a weak but steady trend, and at surface treatment in experiments with various crops ranged between 31 and $96 \%$.

The decreased yield of sunflower in the last two decades was primarily due to the violation of scientifically substantiated placement of this crop in the crop rotation. This significantly worsened the phytosanitary situation in the crops. Sunflower is affected by more than 40 types of diseases. Table-II shows the results of comparative assessment of the efficiency of sunflower seeds treatment against a set of diseases and stem blight in the field.

The obtained data allow making a conclusion that the priority treating agent for sunflower seeds against stem blight should be the Maxim KS preparation from the Syngenta Company with the optimal consumption rate of $8-10$ l per ton of seeds. The Vial Trust preparation from the August Company is also noteworthy; its consumption rate is $0.4-0.5$ 1 per ton of seeds. Besides, the maximum dosage of the studied treaters: Maxim KS - 121 per ton of seeds and Vial Trust - $0.5 \mathrm{l}$ per ton of seeds, ensures higher by $10 \%$ preservation rate of the unaffected plants.

Table-II: Distribution of diseases in sunflower crops in the phase of seed filling and physiological ripeness, \% (2016 - 2018)

\begin{tabular}{|c|c|c|c|c|c|c|c|c|c|}
\hline Variant of experiment & 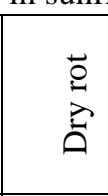 & 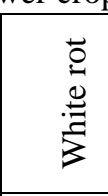 & $\begin{array}{l}\overrightarrow{0} \\
\stackrel{\circlearrowright}{0} \\
\stackrel{0}{U}\end{array}$ & 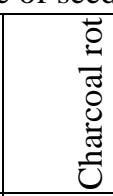 & 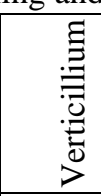 & $\stackrel{\varpi}{\mathscr{2}}$ & $\begin{array}{l}\underset{\Xi}{0} \\
\underset{\Xi}{\Xi} \\
\frac{\Xi}{a}\end{array}$ & 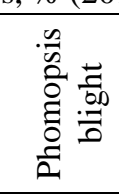 & 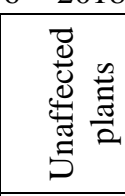 \\
\hline $\begin{array}{lll}\begin{array}{l}\text { Reference } \\
\text { treatment) }\end{array} & \text { (without } & \text { seed } \\
\end{array}$ & 2.20 & 0.32 & 0.00 & 27.70 & 0.25 & 8.08 & 4.75 & 3.80 & 52.20 \\
\hline Vial Trust $-0.3 \mathrm{l}$ per ton of seeds & 2.20 & 0.64 & 0.20 & 28.23 & 0.00 & 7.85 & 5.94 & 1.84 & 53.10 \\
\hline $\begin{array}{l}\text { Maxim KS }-6.0 \text { l per ton of } \\
\text { seeds }\end{array}$ & 1.48 & 1.65 & 0.00 & 29.91 & 0.00 & 6.42 & 4.65 & 0.48 & 55.41 \\
\hline Vial Trust -0.5 l per ton of seeds & 1.06 & 0.87 & 0.00 & 25.72 & 0.35 & 4.05 & 4.93 & 0.35 & 62.67 \\
\hline $\begin{array}{l}\text { Maxim KS - } 12.0 \text { l per ton of } \\
\text { seeds }\end{array}$ & 0.91 & 0.70 & 0.38 & 22.97 & 0.00 & 3.10 & 5.27 & 0.38 & 66.29 \\
\hline
\end{tabular}

The yield is the total indicator of sunflower vital activity that is affected by the factors of pre-sowing treatment of seeds with various chemical treaters ensuring the appropriate yield level. The obtained results are shown in Table-III. It was found that sunflower plants in the reference variant on the background of natural fertility of the experimental plot and the nitrogen-and-phosphorus fertilizers introduced before the main soil tillage had formed the yield at the level of $28.4 \mathrm{hw} / \mathrm{ha}$. The yield rate of sunflower in the other variants was within 30.1 - $36.5 \mathrm{hw} / \mathrm{ha}$, which was by 5.6 $22.2 \%$ higher than in the reference. Plumpness of the seed pod was fairly good with the optimal accumulation of oils.

Table-III: The effect of seed treaters on the sunflower productivity in the conditions of compact chernozems (2016 - 2018)

\begin{tabular}{|c|c|c|c|c|c|}
\hline \multirow{2}{*}{ Variant of experiment } & \multirow{2}{*}{$\begin{array}{c}\text { The weight of } 1,000 \\
\text { seeds, } g\end{array}$} & \multirow{2}{*}{$\begin{array}{l}\text { Oil content in the seeds, } \\
\%\end{array}$} & \multirow{2}{*}{ Yield, hw/ha } & \multicolumn{2}{|c|}{ Increase to the reference } \\
\hline & & & & $\pm \mathrm{hw} / \mathrm{ha}$ & $\%$ \\
\hline Reference (without seed treatment) & 91.4 & 40.6 & 28.4 & - & - \\
\hline Vial Trust $-0.3 \mathrm{l}$ per ton of seeds & 89.7 & 41.8 & 30.1 & 1.7 & 5.6 \\
\hline Maxim KS -6.0 l per ton of seeds & 93.9 & 42.1 & 31.7 & 3.3 & 10.4 \\
\hline Vial Trust $-0.5 \mathrm{l}$ per ton of seeds & 95.8 & 44.0 & 34.9 & 6.5 & 18.6 \\
\hline Maxim KS -12.0 l per ton of seeds & 96.3 & 44.2 & 36.5 & 8.1 & 22.2 \\
\hline $\mathrm{LSD}_{0.5}$ & 1.05 & 0.5 & 0.93 & & \\
\hline
\end{tabular}

Comparative assessment of the yields in the variants show predominance in the yield of the sunflowers treated with the Maxim KS preparation, both at low and high dosages.

The decisive condition for the formation of industrial technologies for tilled crops is sowing with certain plant density. Achieving it depends on soil pests no less than on soil humidity and the agro-physical state. For example, the pre-determined density of sugar beet is really achievable if there are less than two - three wireworms and false wireworms, and less than one larva of May beetle in $1 \mathrm{~m}^{2}$ [13]. 
If there are more than five to ten larvae, thickened sowing is required, which involves additional methods for forming the final density before harvesting, which do not promote resource saving and do not always ensure uniform area of plant nutrition.

The sunflower and maize sowing norm in the experiments was determined from the expectation of obtaining $60-65$ thousand/ha of seedlings. With that, the predetermined number of germinating seeds increased by $10-11 \%$. Deficiency (shortage) of sunflower seedlings ranged over the years with the highly visible effect of the methods of primary tillage. The data about the dynamics of maize density in the experiment are shown in Table-IV.

The greatest deficiency of germination was noted in 2016, after a wet autumn. Among the methods of treatment, it was the highest after shallow tillage, where the excess, compared to plowing, on both fertilizer backgrounds was greater than a third. The lowest shortage of seedlings was noted in 2017 $3.5-4.5 \%$. The positive effect of the combined system of treatments was manifested in a steady, but barely noticeable trend.

Table-IV: Dynamics of plant density of maize for silage, depending on the methods of compact chernozem tillage and fertilization rates

\begin{tabular}{|l|l|l|l|l|}
\hline Year & $\begin{array}{c}|c| \\
\text { deficiency* } \\
\%\end{array}$ & $\begin{array}{c}\text { thousand/ } \\
\text { ha }\end{array}$ & $\begin{array}{c}\text { Decrease during } \\
\text { the vegetation } \\
\text { season, \% }\end{array}$ & $\begin{array}{c}\text { Before } \\
\text { harvesting, } \\
\text { thousand/ha }\end{array}$ \\
\hline \multicolumn{5}{|c|}{ moderate fertilization rate } \\
\hline \multicolumn{5}{|c|}{ plowing to the depth of $25-27$ cm (continuously) } \\
\hline 2016 & 14.0 & 51.6 & 17.1 & 42.8 \\
\hline 2017 & 3.5 & 57.9 & 4.7 & 55.2 \\
\hline 2018 & 7.3 & 55.6 & 2.7 & 54.1 \\
\hline chisel plowing to the depth of $38-40$ cm (continuously) \\
\hline 2016 & 17.7 & 49.4 & 17.0 & 41.0 \\
\hline 2017 & 4.2 & 57.5 & 14.3 & 49.3 \\
\hline 2018 & 5.0 & 57.0 & 2.8 & 55.4 \\
\hline surface tillage to the depth of $10-12$ cm (continuously) \\
\hline 2016 & 20.4 & 46.1 & 14.8 & 39.3 \\
\hline 2017 & 4.5 & 57.3 & 5.4 & 54.2 \\
\hline 2018 & 8.0 & 55.2 & 2.2 & 54.0 \\
\hline combined system of tillage \\
\hline
\end{tabular}

\begin{tabular}{|l|l|l|l|l|}
\hline 2016 & 13.5 & 51.9 & 17.3 & 42.9 \\
\hline 2017 & 3.7 & 57.8 & 3.8 & 55.6 \\
\hline 2018 & 4.7 & 57.2 & 2.6 & 55.7 \\
\hline
\end{tabular}

high fertilization rate

plowing to the depth of $25-27 \mathrm{~cm}$ (continuously)

\begin{tabular}{|l|l|l|l|l|}
\hline 2016 & 12.7 & 52.4 & 9.5 & 47.4 \\
\hline 2017 & 4.5 & 57.3 & 3.3 & 55.4 \\
\hline 2018 & 7.7 & 55.4 & 2.5 & 54.0 \\
\hline
\end{tabular}

chisel plowing to the depth of $38-40 \mathrm{~cm}$ (continuously)

\begin{tabular}{|l|l|l|l|l|}
\hline 2016 & 17.2 & 49.7 & 9.1 & 45.2 \\
\hline 2017 & 4.0 & 57.6 & 4.7 & 54.9 \\
\hline 2018 & 4.8 & 57.1 & 2.8 & 55.4 \\
\hline
\end{tabular}

surface tillage to the depth of $10-12 \mathrm{~cm}$ (continuously)

\begin{tabular}{|l|l|l|l|l|}
\hline 2016 & 23.5 & 45.9 & 9.7 & 44.4 \\
\hline 2017 & 5.2 & 56.9 & 4.2 & 54.5 \\
\hline 2018 & 6.8 & 55.9 & 2.1 & 54.7 \\
\hline combined system of tillage \\
\hline 2016 & 13.3 & 52.0 & 9.2 & 47.2 \\
\hline 2017 & 4.3 & 57.4 & 3.1 & 55.6 \\
\hline 2018 & 5.2 & 56.9 & 1.9 & 55.8 \\
\hline \multicolumn{5}{|c|}{$*(100 \%$ - actual germination in \%). }
\end{tabular}

In the summer 2016, the plant wastes on the background of abundant rain in the spring and the autumn periods were the highest due to the delayed planting caused by waterlogging of the soil at the optimal time for sowing (more than $70 \mathrm{~mm}$ of rainfall occurred in mid-June).

Preservation of maize plants during the vegetation season was positively influenced by the high rate of fertilizers. The decrease in their number in 2016 was two times smaller, compared to similar variants. In other years, this effect was the lowest, although quite noticeable.

Low density of plants before harvesting was noted in 2016 due to the low germination rate and considerable loss of plants in the post-emergence period, and the highest one - in 2017 due to the low deficiency of seedlings in combination with the relatively low amount of plant wastes. Its increase at a high rate of fertilizers amounted to $10-13 \%$.

During all years of the studies and in all variants of the experiment, field germination rate of sunflower was almost the same (Table-V).

Table-V: Dynamics of plant density of sunflower, depending on the methods of compact chernozem tillage and fertilization rates

\begin{tabular}{|c|c|c|c|c|}
\hline \multirow{2}{*}{ Year } & \multicolumn{2}{|c|}{ Seedlings } & \multirow{2}{*}{$\begin{array}{l}\text { Decrease during the } \\
\text { vegetation season, \% }\end{array}$} & \multirow{2}{*}{$\begin{array}{c}\text { Before harvesting } \\
\text { thousand/ha }\end{array}$} \\
\hline & deficiency*, \% & thousand/ha & & \\
\hline \multicolumn{5}{|c|}{ moderate fertilization rate } \\
\hline \multicolumn{5}{|c|}{ plowing to the depth of $25-27 \mathrm{~cm}$ (continuously) } \\
\hline 2016 & 2.5 & 58.5 & 3.4 & 56.5 \\
\hline 2017 & 4.0 & 57.6 & 2.6 & 56.1 \\
\hline 2018 & 4.2 & 57.5 & 16.5 & 48.0 \\
\hline \multicolumn{5}{|c|}{ chisel plowing to the depth of $38-40 \mathrm{~cm}$ (continuously) } \\
\hline 2016 & 3.5 & 57.9 & 2.6 & 56.4 \\
\hline 2017 & 2.5 & 58.5 & 4.3 & 56.0 \\
\hline 2018 & 3.7 & 57.8 & 16.4 & 48.3 \\
\hline \multicolumn{5}{|c|}{ surface tillage to the depth of $10-12 \mathrm{~cm}$ (continuously) } \\
\hline 2016 & 4.2 & 57.5 & 2.5 & 56.0 \\
\hline
\end{tabular}


The Effect of Tillage Methods on the Productivity of Tilled Crops and Soil Fertility

\begin{tabular}{|c|c|c|c|c|}
\hline 2017 & 4.7 & 57.2 & 2.6 & 55.7 \\
\hline 2018 & 2.0 & 58.8 & 12.7 & 51.3 \\
\hline \multicolumn{5}{|c|}{ combined system of tillage } \\
\hline 2016 & 2.2 & 58.7 & 2.2 & 58.7 \\
\hline 2017 & 2.3 & 58.6 & 2.7 & 57.0 \\
\hline 2018 & 1.9 & 58.9 & 11.0 & 52.4 \\
\hline \multicolumn{5}{|c|}{ high fertilization rate } \\
\hline \multicolumn{5}{|c|}{ plowing to the depth of $25-27 \mathrm{~cm}$ (continuously) } \\
\hline 2016 & 3.2 & 58.1 & 1.8 & 57.0 \\
\hline 2017 & 4.3 & 57.4 & 2.4 & 55.9 \\
\hline 2018 & 5.0 & 57.0 & 5.8 & 53.7 \\
\hline \multicolumn{5}{|c|}{ chisel plowing to the depth of $38-40 \mathrm{~cm}$ (continuously) } \\
\hline 2016 & 4.3 & 57.4 & 2.6 & 55.9 \\
\hline 2017 & 2.7 & 58.4 & 3.4 & 56.4 \\
\hline 2018 & 3.5 & 57.9 & 8.6 & 52.9 \\
\hline \multicolumn{5}{|c|}{ surface tillage to the depth of $10-12 \mathrm{~cm}$ (continuously) } \\
\hline 2016 & 4.5 & 57.3 & 3.5 & 55.3 \\
\hline 2017 & 3.5 & 57.9 & 3.5 & 55.9 \\
\hline 2018 & 2.2 & 58.7 & 6.2 & 55.1 \\
\hline \multicolumn{5}{|c|}{ combined system of tillage } \\
\hline 2016 & 2.3 & 58.6 & 1.2 & 58.0 \\
\hline 2017 & 2.7 & 58.4 & 2.6 & 56.9 \\
\hline 2018 & 2.0 & 58.8 & 6.9 & 54.7 \\
\hline
\end{tabular}

More intensive loss of plants over the growing period was noted in 2018 (at the end of May, more than 2.5 precipitation norms fell). The loss of sunflower plants in the variant with the combined system of soil treatment was lower, and at high dosages of the fertilizer, it decreased $2-8$ times.

It should be noted that despite the small deficiency of seedlings over the entire period of the study, it was lower in the case of the combined tillage system. It had a positive effect on plant preservation in 2018, when the sunflower plants waste was the highest.

Thus, the formation of the final density of maize and sunflower before harvesting is complicated by obtaining certain density of germination and loss of plants in the subsequent period due to temporary waterlogging of compact chernozem. It is an unregulated factor, the negative effect of which can be reduced by optimizing the nutrient conditions.

Field germination depends on the seed layer moisture and its agrophysical state. As a result of assessing the correlation between the deficiency of predetermined seedling density and the total porosity of the top layer $(0-10 \mathrm{~cm})$ of compact chernozem, the expert explanation of the differences in the germination rate, depending on the structure of seed layer, has been confirmed, based on practical experience.

The results of this assessment are shown in Table-VI and in Figures 1 and 2.

Table-VI: Results of calculating the correlation between the deficiency of seedlings and the total porosity in the $0-10 \mathrm{~cm}$ layer of compact chernozem

\begin{tabular}{|c|c|c|c|c|}
\hline \multirow{2}{*}{ Water supply conditions* } & \multicolumn{2}{|c|}{ Maize } & \multicolumn{2}{|c|}{ Sunflower } \\
\hline & $r$ & $\mathrm{r}^{2}$ & $\mathrm{r}$ & $\mathrm{r}^{2}$ \\
\hline On average & 0.82 & 0.68 & 0.68 & 0.47 \\
\hline Arid & 0.99 & 0.98 & 0.95 & 0.91 \\
\hline Normal and humid & 0.95 & 0.91 & 0.84 & 0.71 \\
\hline
\end{tabular}

With the use of all data (without separation by the humidity conditions) about germination and total porosity in the experiments, as well as the published results of other studies at the Adygea Scientific Research Institute of Agriculture [14], [15], [16], it was proven that the size and the strength of the relationship were insufficient for making regression equations for practical purposes. The characteristics of the correlation with regard to the aridity were quite acceptable. For maize, they were somewhat better than for sunflower. This is evident from comparing Figures 1 and 2. 


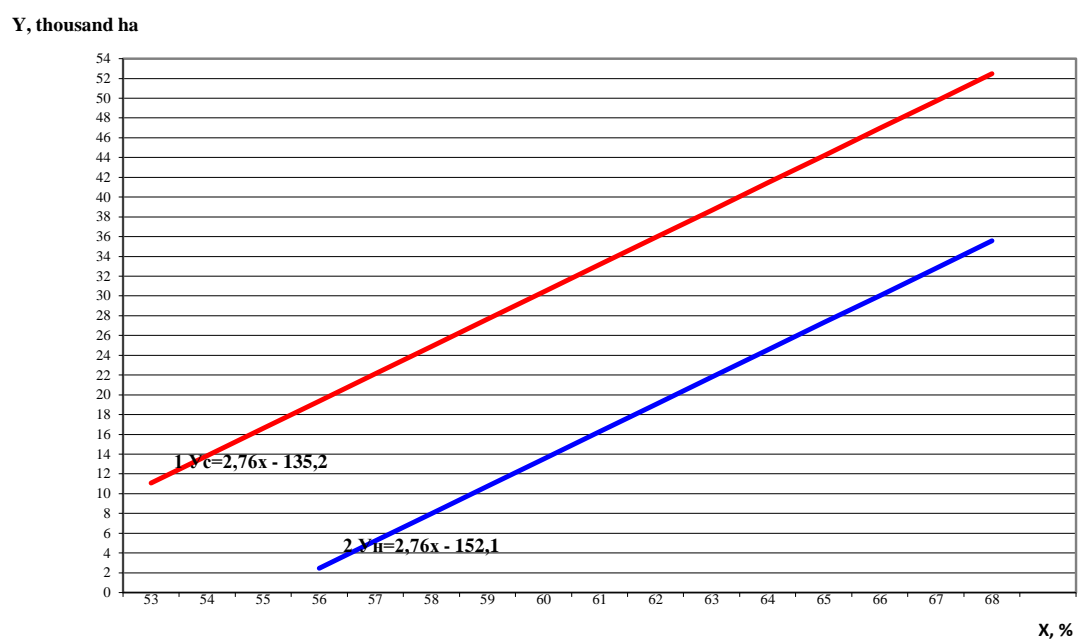

Fig. 1. The relationship between deficiency of certain density of maize seedlings $(\Delta Y)$ and the total porosity $(\mathrm{X})$ in the $0-10$ cm layer of compact chernozem. Conditions: 1 - drought; 2 - norm.

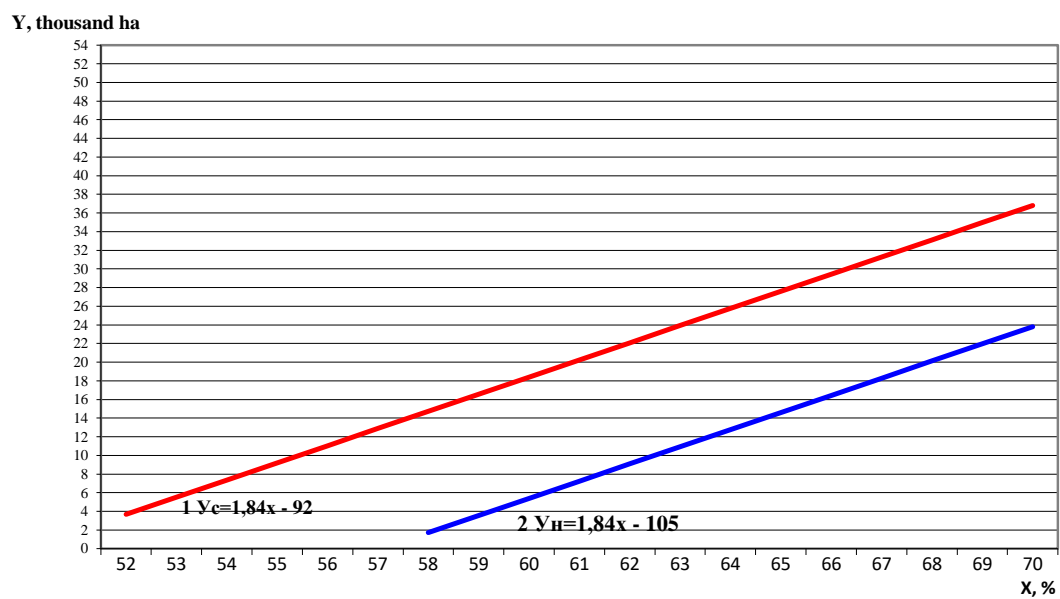

Fig. 2. The relationship between deficiency of certain density of sunflower seedlings $(\Delta Y)$ and the total porosity $(\mathrm{X})$ in the $0-$ $10 \mathrm{~cm}$ layer of compact chernozem. Conditions: 1 - drought; 2 - norm.

The regression equations are the following:

a) for maize

$\Delta \mathrm{Yc}=2.76 \mathrm{X}-135.2$ (thousand ha)

$\Delta \mathrm{Yn}=2.76 \mathrm{X}-152.1$ (thousand ha)

b) for sunflower

$\Delta \mathrm{Yc}=1.84 \mathrm{X}-92$ (thousand ha)

$\Delta \mathrm{Yn}=1.84 \mathrm{X}-152.1$ (thousand ha),

where $\Delta \mathrm{Yc}$ and $\Delta \mathrm{Yn}$ are the adjustments to the seeding norm of viable seeds (in \%), with regard to the structure of the seed layer of compact chernozem, $\mathrm{X}$ is the total porosity (in \%). It should be borne in mind that $\Delta \mathrm{Y}$ has no practical value, the role of these equations (for arid conditions) is just confirmation.

In determining additions to the seeding rate at certain seedling density, one should be guided only by the equations for the conditions of normal water supply $(\Delta \mathrm{Yn})$ because the precipitation in the post-harvesting period creates the risk of crops thickening with all the negative consequences.

In the studies, the yield depended on a number of often interrelated factors: the weather conditions; the agro-physical soil conditions that significantly affected the water and nutrient conditions; the provision of moisture and nutrients; and the phytosanitary state of the crops. They determined the proximity of crops density to the optimum parameters, which significantly affected the yield of the crops. During the research, the combination of these factors varied, therefore, the yields varied both over the years, and due to the influence of the variants of the experiments.

Upon the introduction of high rates of fertilizers in the variant with combined tillage, the yield of maize for silage was higher both on average, and over the years of the research study (see Table-VII). However, the gain from the choice of tillage (in terms of the fertilizer introduction norms) was insignificant. From increasing the level of fertilization, it was the following: at plowing $-82.5 \mathrm{hw} / \mathrm{ha}$, or $24 \%$; at chisel tillage - $71.6 \mathrm{hw} / \mathrm{ha}$, or $22 \%$; at surface tillage $71.2 \mathrm{hw} / \mathrm{ha}$, or $22 \%$; and in the variant of adjustable tillage - $77.0 \mathrm{hw} / \mathrm{ha}$, or $18 \%$.

The positive role of alternating primary tillages, based on their choice, was very clearly manifested in the yield of sunflower (the third crop in the crop rotation link). Its growth in this variant with moderate fertilization in 2016 amounted to $10-13 \%$, and $9-10 \%$ in 2017 , and with high fertilization rate - to $8-22 \%$ and $11-17 \%$, respectively. The gain from increasing the fertilization rate was high, and amounted to the following values: at plowing — to 4.5 hw/ha, or $20 \%$; at chisel plowing - to $6.1 \mathrm{hw} / \mathrm{ha}$, or $27 \%$; and at surface tillage — to $5.6 \mathrm{hw} / \mathrm{ha}$, or $24 \%$.

Blue Eyes Intelligence Engineering 


\section{The Effect of Tillage Methods on the Productivity of Tilled Crops and Soil Fertility}

The highest yields were obtained in the variant with

$31 \%$. combined system of tillage; they amounted to $7.4 \mathrm{hw} / \mathrm{ha}$, or

Table-VII: The yield of crops depending on tillage and fertilization rates, hw/ha

\begin{tabular}{|c|c|c|c|c|c|c|c|c|c|c|}
\hline \multirow{3}{*}{ Year } & \multirow{2}{*}{\multicolumn{2}{|c|}{$\begin{array}{c}\text { Plowing, } 25-27 \mathrm{~cm} \\
\text { fertilization rate }\end{array}$}} & \multirow{2}{*}{\multicolumn{2}{|c|}{$\begin{array}{l}\text { Chisel plowing, } 38- \\
40 \mathrm{~cm} \\
\text { fertilization rate }\end{array}$}} & \multirow{2}{*}{\multicolumn{2}{|c|}{$\begin{array}{c}\text { Surface tillage, } 10 \mathrm{~cm} \\
\text { fertilization rate }\end{array}$}} & \multirow{2}{*}{\multicolumn{2}{|c|}{$\begin{array}{c}\text { Combined } \\
\text { fertilization rate }\end{array}$}} & \multirow{3}{*}{$\mathrm{P}, \%$} & \multirow{3}{*}{$\begin{array}{l}\mathrm{LSD}_{0.5} \\
\text { hw/ha }\end{array}$} \\
\hline & & & & & & & & & & \\
\hline & moderate & high & moderate & high & moderate & high & moderate & high & & \\
\hline \multicolumn{11}{|c|}{ maize for silage } \\
\hline $2016(1)$ & 362.4 & 434.4 & 321.7 & 393.6 & 328.2 & 380.9 & 367.2 & 441.2 & 3.3 & 30.8 \\
\hline $2017(1)$ & 321.5 & 386.6 & 307.8 & 367.5 & 297.4 & 375.0 & 319.6 & 393.5 & 5.4 & 39.7 \\
\hline $2018(2)$ & 335.5 & 443.0 & 367.6 & 450.9 & 344.1 & 427.2 & 378.1 & 461.4 & 3.6 & 40.0 \\
\hline average & 339.8 & 422.3 & 332.4 & 404.0 & 323.2 & 394.4 & 355.0 & 432.0 & & \\
\hline \multicolumn{11}{|c|}{ sunflower } \\
\hline $2016(1)$ & 20.2 & 25.0 & 18.1 & 22.4 & 17.6 & 23.2 & 19.9 & 26.4 & 3.7 & 2.3 \\
\hline $2017(1)$ & 19.7 & 24.8 & 20.2 & 30.1 & 19.9 & 26.6 & 21.6 & 30.0 & 6.2 & 5.1 \\
\hline $2018(2)$ & 28.2 & 31.9 & 28.5 & 32.6 & 31.0 & 35.4 & 29.7 & 36.8 & 3.2 & 3.1 \\
\hline average & 22.7 & 27.2 & 22.3 & 28.4 & 22.8 & 28.4 & 23.7 & 31.1 & & \\
\hline
\end{tabular}

Note: Column "Year" in parentheses contains primary tillages in the variant with combined system: (1) plowing, (2) chiseling, (3) surface tillage.

In general over the experiment, in the context of the fertilization norms, high yields of maize and sunflower (both in individual years and on average) were obtained in the variant with the use of combined system of tillage. The biological requirements for maize hybrids and varieties in terms of the external conditions that ensure timely and aligned germination, rapid growth and development in the initial period are well known.

The yield rates of white-grain food maize in this experiment, depending on the fertilization rates, methods of the primary tillage, and the time of sowing are shown in Table-VIII.
The most significant and unambiguous result of the research study over the years was the yield growth caused by the use of fertilizers, which reached the maximum at $\mathrm{N}_{90} \mathrm{P}_{90} \mathrm{~K}_{90}$ regardless of the tillage method and the date of sowing. Increasing the fertilization rate to $\mathrm{N}_{120} \mathrm{P}_{120} \mathrm{~K}_{120}$ did not provide further increase of the yields.

In the reference (not fertilized) variant, the advantage of plowing with treatment with BDT-7 on average over the period of the study exceeded $8 \%$ at the first sowing date, and almost half at the second plowing. This difference in the most promising variant of fertilization with $\mathrm{N}_{90} \mathrm{P}_{90} \mathrm{~K}_{90}$ was about the same.

Table-VIII: The yield rate of the Adygeiskaya white-grained food maize, depending on the time of sowing and dosages of mineral fertilizers at various tillage methods, hw/ha (2016 - 2018)

\begin{tabular}{|c|c|c|c|c|c|c|c|c|}
\hline \multirow{2}{*}{$\begin{array}{c}\text { Variant of } \\
\text { experiment }\end{array}$} & \multirow{2}{*}{2016} & \multirow{2}{*}{2017} & \multirow{2}{*}{2018} & \multirow{2}{*}{$\begin{array}{c}\text { Average yield rate over the } \\
\text { years }\end{array}$} & \multicolumn{3}{|c|}{ Average for: } & \multirow{2}{*}{$\begin{array}{l}\text { AB interaction } \\
\text { effect }\end{array}$} \\
\hline & & & & & variants & factor A & factor B & \\
\hline \multicolumn{9}{|c|}{ ploughing with PLN-5-35, the first date of sowing (recommended) } \\
\hline $\begin{array}{c}\text { Reference (w/o } \\
\text { fertilization) }\end{array}$ & 47.3 & 31.8 & 59.2 & 46.1 & 46.1 & & & -0.04 \\
\hline $\mathrm{N}_{60} \mathrm{P}_{60} \mathrm{~K}_{60}$ & 58.0 & 32.9 & 68.9 & 53.3 & 53.3 & 53.09 & & -0.24 \\
\hline $\mathrm{N}_{90} \mathrm{P}_{90} \mathrm{~K}_{60}$ & 63.7 & 33.8 & 74.1 & 57.2 & 57.2 & & & 0.39 \\
\hline $\mathrm{N}_{120} \mathrm{P}_{120} \mathrm{~K}_{60}$ & 60.2 & 33.4 & 73.8 & 55.8 & 55.8 & & & -0.11 \\
\hline \multicolumn{9}{|c|}{ plowing with PLN-5-35, the second time of sowing* } \\
\hline $\begin{array}{c}\text { Reference (w/o } \\
\text { fertilization) }\end{array}$ & 41.8 & 20.8 & 45.6 & 36.1 & 36.1 & & 41.04 & 0.04 \\
\hline $\mathrm{N}_{60} \mathrm{P}_{60} \mathrm{~K}_{60}$ & 52.7 & 21.6 & 56.6 & 43.6 & 43.6 & 42.97 & 48.45 & 0.24 \\
\hline $\mathrm{N}_{90} \mathrm{P}_{90} \mathrm{~K}_{60}$ & 56.4 & 22.3 & 60.2 & 46.3 & 46.3 & & 51.75 & -0.39 \\
\hline $\mathrm{N}_{120} \mathrm{P}_{120} \mathrm{~K}_{60}$ & 54.8 & 22.1 & 60.8 & 45.9 & 45.9 & & 50.85 & 0.11 \\
\hline \multicolumn{5}{|c|}{$\operatorname{LSD}_{0.5}$} & 6.93 & 3.47 & 4.90 & 6.93 \\
\hline \multicolumn{9}{|c|}{ tillage with BDT-7, the first date of sowing (recommended) } \\
\hline $\begin{array}{c}\text { Reference (w/o } \\
\text { fertilization) }\end{array}$ & 42.7 & 28.9 & 56.2 & 42.6 & 42.6 & & & -0.37 \\
\hline $\mathrm{N}_{60} \mathrm{P}_{60} \mathrm{~K}_{60}$ & 53.6 & 30.4 & 65.5 & 49.8 & 49.8 & 49.30 & & 0.31 \\
\hline $\mathrm{N}_{90} \mathrm{P}_{90} \mathrm{~K}_{60}$ & 57.7 & 31.3 & 70.3 & 53.1 & 53.1 & & & 0.26 \\
\hline
\end{tabular}




\begin{tabular}{|c|c|c|c|c|c|c|c|c|}
\hline $\mathrm{N}_{120} \mathrm{P}_{120} \mathrm{~K}_{60}$ & 55.4 & 30.1 & 69.5 & 51.7 & 51.7 & & & -0.20 \\
\hline \multicolumn{9}{|c|}{ tillage with BDT-7, the second date of sowing } \\
\hline $\begin{array}{c}\text { Reference (w/o } \\
\text { fertilization) }\end{array}$ & 38.7 & \begin{tabular}{|l|l}
18.7 \\
\end{tabular} & 45.7 & 34.4 & 34.4 & & 38.48 & 0.37 \\
\hline $\mathrm{N}_{60} \mathrm{P}_{60} \mathrm{~K}_{60}$ & 47.0 & 19.7 & 54.0 & 40.2 & 40.2 & 40.33 & 45.03 & -0.31 \\
\hline $\mathrm{N}_{90} \mathrm{P}_{90} \mathrm{~K}_{60}$ & 51.8 & 20.2 & 58.8 & 43.6 & 43.6 & & 48.35 & 0.26 \\
\hline $\mathrm{N}_{120} \mathrm{P}_{120} \mathrm{~K}_{60}$ & 50.7 & 20.1 & 58.5 & 43.1 & 43.1 & & 47.38 & 0.20 \\
\hline \multicolumn{5}{|c|}{$\mathrm{LSD}_{0.5}$} & 6.07 & 3.04 & 4.29 & 6.07 \\
\hline
\end{tabular}

In the abnormally arid year 2017, the differences due to the methods of tillage were the following: in the reference variants -10 and $11 \%$ at the first and second sowing, respectively; in the variant with fertilization $\left(\mathrm{N}_{90} \mathrm{P}_{90} \mathrm{~K}_{90}\right)$, they reduced to $8 \%$ at the first sowing, and were insignificant at the second sowing. The differences caused by sowing dates were much more significant. On average over the three years, the advantage of the first sowing date was the following: at plowing $-28 \%$ in the reference and $24 \%$ in the variant with $\mathrm{N}_{90} \mathrm{P}_{90} \mathrm{~K}_{90}$; at harrowing with BDT-7 - $24 \%$ and $22 \%$, respectively.

As a result of the studies, the authors determined the share of effects of the values of dispersion types in forming the yields of white-grained food maize of the Adygeiakaya variety at plowing (PLN-5-35) to the depth of $25-27 \mathrm{~cm}$ and at surface tillage (BDT-7) to the depth of $10-12 \mathrm{~cm}$.

The two-factor analysis of variance showed that the share of the effect of total variation on the grain yield of maize was $30.2 \%$. Here the environmental factors played the dominant role. The share of the effect of variants of the experiment with plowing with PLN-5-35 (the time of sowing and dosages of fertilizers) was $29.8 \%$. The share of the effect of factor A (the date of sowing) on the yield was $20.3 \%$. The share of the effect of factor B (dosage of fertilizer) was $19.7 \%$, and the share of the controlled factors amounted to $69.8 \%$.

The share of the total variation on maize grain yield at surface tillage with BDT-7 was $38.5 \%$. This is a very high share of environmental factors on the grain yield. The share of the variants of the experiment (the dates of sowing and dosages of mineral fertilizers) in the productivity of maize was $29.8 \%$. The share of the time of sowing was $20.2 \%$, and mineral fertilizers had little effect on the grain yield of maize, which was $14.6 \%$. The share of the controlled factors was $61.5 \%$.

\section{CONCLUSION}

Among the methods of primary tillage, the lowest weed infestation was observed after plowing: the number and the mass of perennial weeds before maize and sunflower harvesting was less by $30-80 \%$ than in the case of continuous surface tillage. An increase in the number of harmful larvae in the variant with continuous surface tillage, compared to plowing over the experiments and crops, was in the range between 31 and $96 \%$, and in the case of chisel tillage, it was manifested as a sustainable trend. Replacement of plowing with heavy disc harrowing resulted in the increased number of maize plants damaged by stem moth by $13 \%$ at the recommended date of sowing, and by $24 \%$ at the late date of sowing.

Formation of the optimal maize and sunflower plant density

before harvesting on compact chernozem is hampered by the decreased germination with loose structure of the seed layer, and loss of plants during the growing season in the case of abundant rainfall over a short period. The loss of maize and sunflower plants during the vegetation season in some years exceeded $30 \%$, but on heavily fertilized background it was $1.7-2.6$ times lower.

The differences in the agrophysical and agrochemical properties of the soil, and the phytosanitary state of the agrocenoses in the context of the studied methods were significantly manifested in the yield of tilled crops. The differences in sunflower yield over the years were often the opposite, depending on the methods of compact chernozem primary tillage. The highest average yield was achieved in the variant with combined (based on the choice) system of tillage. The gain due to increasing the fertilization rates ranged from $20 \%$ (at plowing) to $31 \%$ (at combined tillage). The decrease in the yield of grain maize after replacing plowing of compact chernozem with heavy disc harrowing did not exceed $8 \%$, and in the case of long-delayed sowin, it was at the level of $19-28 \%$.

\section{ACKNOWLEDGMENT}

The research study was performed within State Assignment for 2017 - 2019 on the topic "Theory and Principles of Developing Modern Agricultural Technologies for Preserving and Reproducing Soil Fertility, Efficient Use of Natural Resource Potential of Cultivated Land in Organic Agricultural Production". State reg. No. AAAA-A 17-117030110085-9 GZ 1-17.

\section{REFERENCES}

1. V.I. Kiryushin, A.L. Ivanov, "Agroekologicheskaya otsenka zemel, proektirovanie ALSZ i agrotekhnologii”: Metodicheskoe rukovodstvo [Agroecological assessment of lands, designing ALFS and agricultural technologies: Methodical manual]. Moscow: FGSE Rosinformagrotech, 2005, pp. 783.

2. A.M. Elmesov, "Tekhnologiya proizvodstva kukuruzy (obrabotka pochvy)" [The technology of maize production (tillage)]: Scientific edition. Nalchik: Elbrus, 2000, pp. 261.

3. V.M. Kildyushkin, V.K. Bugayevsky, A.A. Romanenko, “Osnovnaya obrabotka pochvy $\mathrm{v}$ erozionnoopasnykh i ravninnozapadinnykh agrolandshaftakh Severnogo Kavkaza" [Primary tillage of the soil in erosion-hazardous and plain-pit cultivated lands of North Caucasus]. Achievements of science and technology of agriculture, 11, 2004, pp. 25 $-26$.

4. N.I. Mamsirov, "Optimizatsiya sistemy obrabotki pochv kak faktor povysheniya ikh plodorodiya i produktivnosti propashnykh kultur": Monografiya [Optimizing the system of tillage as a factor of increasing soil fertility and productivity of cultivated crops: Monograph]. Maikop: Publishing house Magarin O.G., 2015, pp. 287. 


\section{The Effect of Tillage Methods on the Productivity of Tilled Crops and Soil Fertility}

5. N.I. Mamsirov, "Optimizatsiya sistemy obrabotki pochv kak faktor povysheniya ikh plodorodiya i produktivnosti propashnykh kultur v usloviyakh yuzhno-predgornoi zony Zapadnogo Predkavkazya" [Optimization of the tillage system as a factor of increasing soil fertility and productivity of cultivated crops in the southern Piedmont zone of the Western Ciscaucasia]: Dis. ... Dr. of Agricultural Sciences. Vladikavkaz, 2016, pp. 357.

6. A.S. Naydenov, V.V. Tereshchenko, N.I. Bardak, "Polozhitelnoe i otritsatelnoe vliyanie minimizatsii obrabotki chernozemnykh pochv" [The positive and negative effect of minimizing tillage of chernozem soils]. Krasnodar, Agroecological monitoring in the agriculture of the Krasnodar Krai, 431(459), 2008, pp. $234-240$.

7. N.I. Mamsirov, Y.A. Chumachenko, A.C. Udzhuhu, "Agrochemical properties of fused chernozem, depending on the methods of basic processing and the norms of fertilization”. Ecology, Environment and Conservation Paper, 24(1), 2018, pp. 462 - 471.

8. N.I. Mamsirov, R.K. Tuguz, K.K. Khatkov, J.A. Shaova, Z.S. Daguzhieva, "Changes in Agrophysical Properties of Compact Chernozem Depending on the Soil Treatment Methods". World Applied Sciences Journal, 26(3), 2013, pp. 312 - 317.

9. L.M. Derzhavin, D.S. Bulgakov, "Metodicheskie ukazaniya po provedeniyu kompleksnogo monitoringa plodorodiya pochv zemel selskokhozyaistvennogo naznacheniya" [Guidelines for comprehensive monitoring fertility of agricultural lands]. Moscow: FGSE Rosinformagrotech, 2003, pp. 240.

10. V.N. Pisarenko, "Izmenenie chislennosti vreditelei osnovnykh zernovykh kultur v sevooborotakh" [Changing the number of pests of the main crops in crop rotations]. Collection. Ways of increasing the productivity of grain crops in the steppe crop rotations of the Ukrainian SSR. Dnepropetrovsk, 1976, pp. 136 - 141.

11. V.N. Pisarenko, "Biotsenoticheskaya rol agrotekhnicheskikh priemov" [The biocenotic role of agronomic practices]. Plant protection, 9, 1984, pp. $25-26$.

12. N.N. Tretyakov, Y.I. Chirkov, V.H. Zubenko, "Spravochnik kukuruzovoda" [Reference book of a maize breeder], Moscow: Rosselkhozizdat, 1985, pp. 191.

13. I.I. Gureev, "Sovremennye tekhnologii vozdelyvaniya i uborki sakharnoi svekly" [Modern technologies of sugar beet cultivation and harvesting]: Monograph. Moscow: Pechatny gorod, 2011, pp. 256.

14. V.V. Kaun, "1) Obrabotka pochvy tyazhelogo mekhanicheskogo sostava v sevooborotakh". [Tillage of soil with heavy mechanical composition in crop rotations.] 2) Elementy agrotekhniki kukuruzy: nauchnoe izdanie [Elements of maize agronomy: scientific edition]. Maykop, 2008, pp. 94.

15. R.K. Tuguz, "Nauchnoe obosnovanie sistem i sposobov obrabotki slitogo chernozema v Respublike Adygeya": Nauchnoe izdanie [Scientific substantiation of the systems and methods of compact chernozem tillage in the Republic of Adygea: Scientific edition] Maikop: O.G. Magarin Publishing House, 2011, pp. 272.

16. Y.A. Chumachenko, "Kompleksnaya otsenka ekologicheskogo potentsiala pochvennogo pokrova Respubliki Adygeya" [Comprehensive assessment of the ecological potential of the soil cover in the Republic of Adygea]. Moscow: Materials of the IV Congress of the Dokuchaev society of soil scientists, 2004, pp. 264. 